\title{
ANALISIS TINGKAT KESEHATAN BANK PT. BANK PERKREDITAN RAKYAT GANTO NAGARI 1954 LUBUK ALUNG
}

\author{
Siska Ayu Putri, Jhon Fernos \\ Akademi Keuangan dan Perbankan "Pembangunan" Padang \\ sayu9953@gmail.com \\ jhonfernos@akbpstie.ac.id
}

\begin{abstract}
The purpose of this research was to find out how Bank Soundness at PT. Ganto Nagari Rural Bank 1954 Lubuk Alung. The research method used is a method of qualitative and quantitative data analysis. The type of data used is secondary data obtained from Bank Indonesia publication reports and the Ganto Nagari Rural Bank 1954 Lubuk Alung 2016-2017 period. The results of this study indicate that the level of CAR is in a healthy position. The KAP level is in a healthy position, and the Profitability Ratio, Liquidity is also in a healthy position.
\end{abstract}

Keyword: Bank, CAMEL

\section{PENDAHULUAN}

Pertumbuhan bank di Indonesia menjadikan suatu persaingan yang ketat antara bank yang satu dengan yang lainnya dalam mencari nasabah. menurut (Indonesia, 2004)Undang-undang Nomor 10 tahun 1998 tentang perbankan, Bank adalah Badan usaha yang menghimpun dana dari masyarakat dalam bentuk simpanan, dan menyalurkan kembali dalam bentuk kredit dan bentuk lainnya dalam rangka meningkatkan taraf hidup rakyat banyak. Menurut (Putri \& Doni, 2018) Bank adalah suatu badan usaha yang berfungsi menghimpun dana dari masyarakat dalam bentuk simpanan dan menyalurkannya kepada masyarakat dalam bentuk kredit dan bentuk lainnya dalam rangka meningkatkan taraf hidup rakyat banyak.

Bank dibagi menjadi dua yaitu Bank Umum adalah suatu bank yang melaksanakan kegiatan usaha yang secara konvensional dan atau berdasarkan prinsip syariah yang dalam kegiatannya memberikan jasa dalam lalu lintas pembayaran. Sedangkan Bank Perkreditan Rakyat adalah Bank yang melaksanakan kegiatan usaha yang secara konvensional dan atau berdasarkan prinsip syariah yang dalam kegiatan yang dilakukannya tidak memberikan jasa dalam lalu lintas pembayaran.Pada zaman sekarang BPR memiliki peluang, Masyarakat desa pada umumnya banyak mempercayakan dananya pada BPR, baik dalam penyimpanan maupun pinjaman dana tergantung pada usahanya. Pada umumnya masyarakat yang memiliki usaha 
menengah kebawah lebih banyak memilih Bank Perkreditan Rakyat sebagai tempat untuk mengembangkan usahanya melalui pinjaman dengan bunga kecil serta prosedur pemimjamannya mudah dan didukung oleh manajemen itu sendiri.

Bank Indonesia mempunyai tugas dalam mengawasi kegiatan operasional bank, yaitu berdasarkan surat keputusan bank Indonesia No. 30/12/KEP/DIR dan Surat Edaran Bank Indonesia No. 30/3/UPPB tanggal 30 April 1997 (Anggraeni, 2011)

Penilaian dilakukan dengan mengkualifikasikan beberapa komponen yaitu komponen Capital, Asset, Management, Earning, Liquidity, atau singkat dengan istilah CAMEL. Apabila bank mengalami masalah pada salah satu komponen tersebut maka bank akan mengalami kesulitan. Pada analisis CAMEL kriteria yang ditetapkan Bank Indonesia adalah tentang seberapa besar presentase kinerja keuangan yang memenuhi persyaratan bank tersebut untuk dinyatakan sehat, serta tidak membahayakan atau merugikan pihak-pihak yang berpentingan. Analisis CAMEL di kuantifikasikan sebagai aspek penilaian dalam perhitungan rasio keuangan. Oleh karena itu rasio keuangan bermanfaat dalam menilai tingkat kesehatan bank(Anggraeni, 2011).

Tingkat kesehatan bank adalah hasil penelitian kualitatif atas berbagai aspek yang berpengaruh terhadap kondisi atau kinerja suatu Bank atau UUS melalui : penilaian kuantitatif dan penilaian kualitatif terhadap faktor-faktor permodalan kualitas asset, rentabilitas, likuiditas, sensitivitas terhadap resiko pasar dan penilaian kualitatif terhadap faktor manajemen (Bank \& Nawir, 2016).

Semakin tinggi skala operasi bank serta total aset dan jumlah modal, maka kinerja bank semakin baik.Bank yang sehat yaitu bank yang bisa menjalankan tujuan dan fungsinya dengan baik. Dalam penilaian tingkat kesehatan sebuah bank tidak hanya berlaku pada bank-bank umum atau bank besar lainnya saja, hal ini juga berlaku pada semua bank yang ada, termasuk bank-bank daerah atau biasa dikenal dengan Bank Perkreditan Rakyat yang mana bank ini tidak menggunakan jasa lalu lintas pembayaran. Bank Perkreditan Rakyat yaitu salah satu dari sistem perbankan yang dipercaya oleh masyarakat. Kesehatan Bank Perkreditan Rakyat adalah suatu bentuk penilaian konsumen atau masyarakat terhadap tingkat perkembangan suatu bank yang mana nantinya menjadi pengaruh besar bagi masyarakat untuk bergabung pada bank tersebut.Bank yang sehat dijadikan sebagai acuan oleh masyarakat bahwa bank tersebut mampu berkembang dan dapat bersaing serta mampu bertahan pada masanya.

PT. BPR Ganto Nagari 1954 Lubuk Alung yang berlokasikan di Jl. Jendral Sudirman No. 22 Lubuk Alung- Kecamatan Lubuk Alung- Kabupaten Padang Pariaman-Sumatera Barat. BPR ini berperan memberikan kontribusi untuk keberhasilan pembangunan khususnya di bidang penyedian modal untuk masyarakat.Salah satu indikator ynag digunakan untuk menilai keberhasialan atau kegagalan Bank Perkreditan Rakyat dalam mencapai tujuan tersebut adalah laporan keuangan perusahaan yang telah dicapai. Penilaian kinerja keuangan suatu Bank Perkreditan Rakyat sangat penting untuk mencapai laba, serta untuk peningkatan dan perkembangan PT. BPR Ganto Nagari 1954 Lubuk Alung untuk periode berikutnya. 
Laporan mengenai data keuangan PT. BPR Ganto Nagari 1954 Lubuk Alungpada periode2016-2017, dapat dilihat dari tabel berikut :

\section{Tabel 1}

Data Keuangan PT. BPR Ganto Nagari 1954 Lubuk Alung

Tahun 2016-2017

(Rp.000)

\begin{tabular}{llrr}
\hline \multirow{2}{*}{ No } & \multicolumn{1}{c}{ Indikator } & \multicolumn{2}{c}{ Tahun } \\
\cline { 3 - 4 } 1 & & \multicolumn{1}{c}{$\mathbf{2 0 1 6}$} & $\mathbf{2 0 1 7}$ \\
2 & Modal & 2.721 .650 & 2.981 .570 \\
3 & ATMR & 22.531 .922 & 24.710 .701 \\
4 & Laba sebelum pajak & 582.570 & 580.722 \\
5 & Total asset & 27.664 .542 & 31.384 .033 \\
6 & Kredit yang diberikan & 20.011 .576 & 21.895 .300 \\
7 & Dana Pihak Ketiga & 22.549 .582 & 25.660 .345 \\
& APYD & 2.104 .454 & 1.917 .490 \\
\cline { 3 - 4 } & Jumlah Asset Produktif & $\mathbf{1 9 . 5 6 6 . 7 3 8}$ & $\mathbf{2 0 . 8 7 4 . 6 6 8}$
\end{tabular}

Sumber: Laporan Keuangan PT. BPR Ganto Nagari 1954 Lubuk Alung

Tabel 1 Mengidentifikasikan bahwa terdapat fluktuasi atau ketidak tepatan rasio, karena adanya peningkatan dan penurunan nilai keuangan, seperti modal Capital Adeguacy Ratio (CAR), ATMR, laba sebelum pajak, total asset, kredit yang diberikan, dana pihak ketiga, APYD, dan jumlah asset produktif dari PT. Bpr Ganto Nagari 1954 Lubuk Alung.

Capital Adeguacy Ratio (CAR) berdasarkan standar Bank Indonesia minimal 8\% tergolong sehat pada tahun 2016 CAR PT. BPR Ganto Nagari 1954 Lubuk Alung pada modal 2016 adalah Rp 2.721.650 dan tahun 2017 Rp 2.981 .570 artinya modal PT. BPR Ganto Nagari 1954 Lubuk alung tergolong sehat. Untuk ATMR pada tahun 2016 sebesar Rp 22.531.922 dan ditahun 2017 sebesar Rp 24.710.701, berarti ATMR dari tahun 2016 ke tahun 2017 mengalami peningkatan sebanyak Rp 2.178.779 yang tergolong sehat.Untuk laba sebelum pajak dari tahun 2016 dan 2017 mengalami penurunan sebesar Rp 1.848. Untuk total aktiva dari tahun 2016 dan 2017 mengalami peningkatan sebesar Rp 3.719.491. Untuk kredit yang diberikan dari tahun 2016 dan 2017 mengalami peningkatan sebesar Rp 1.883.724.Untuk dana pihak ketiga dari tahun 2016 dan 2017 mengalami peningkatan sebanyak Rp 3.110.763. Sedangkan untuk APYD dari tahun 2016 dan 2017 mengalami pengurangan sebesar Rp 186.964. akan tetapi pada jumlah aset produktif dari tahun 2016 dan 2017 mengalami peningkatan sebesar Rp 1.775.960.

Secara keseluruhan rasio keuangan PT. BPR Ganto Nagari 1954 Lubuk Alung tahun 2016 dan 2017 mengalami peningkatan, namun laba sebelum pajak dari tahun 2016 dan 2017 mengalami penurunan, serta untuk APYD tahun 2016 dan 2017 juga mengalami penurunan. Melihat kenyataan di atas, maka sangat penting bagi bank 
untuk menganalisis tingkat kesehatan bank untuk mempertahankan kelangsungan operasional perusahaan dalam menghadapi persaingan.Oleh karena itu untuk menganalisis tingkat kesehatan bank dapat menggunakan metode CAMEL yaitu Capital, Aset Quality, Management, Earning, dan Liquidity.

Berdasarkan latar belakang yang diuraikan diatas, maka penulis tertarik untuk mengambil judul " Analisis Tingkat Kesehatan PT. Bank Perkreditan Rakyat Ganto Nagari 1954 Lubuk Alung"dengan menggunakan metode CAMEL.

Berdasarkan uraian latar belakang diatas, maka rumusan masalah dalam penelitian ini adalah "Bagaimana tingkat kesehatan bank pada PT. Bank Perkreditan Rakyat Ganto Nagari 1954 Lubuk Alung dengan menggunakan metode CAMEL selama periode 2016 dan 2017 berada dalam kondisi sehat?

\section{LANDASAN TEORI Pengertian Bank}

Istilah bank berasal dari bahasa Italia yaitu Banco yang diubah kedalam bahasa Inggris yaitu bank.Bank adalah salah satu lembaga keuangan sebagai tempat bagi perusahaan, Badan-badan pemerintahan swasta maupun perorangan untuk menyimpan Dana-dananya. Sedangkan menurut (Simorangkir, 2012) mengemukakan, Bank yaitu badan usaha lembaga keuangan yang bertujuan memberikan kredit dan jasa-jasa.

Menurut (M.Pd. Abdullah Thamrin prof Dr, n.d.)Bankadalah sebuah intermediasi keuangan yang didirikan dengan kewenangan untuk menerima simpanan uang, banknote.

\section{Pengertian Bank Perkreditan Rakyat}

Bank Perkreditan Rakyat menurut (Sukmadi, 2014) adalah bank yang berfungsi menghimpun dana dari masyarakat dalam bentuk simpanan yang berupa deposito berjangka atau tabungan serta pemberian kredit.

Asas, Tujuan, Fungsi, dan Sasaran Bank Perkreditan Rakyat

Dalam melaksanakan usahanya Bank Perkreditan Rakyat berasaskan demokrasi ekonomi dengan menggunakan prinsip kehati-hatian.Tujuan beserta Fungsi Bank Perkreditan Rakyat adalah menghimpun dana dari masyarakat dalam bentuk simpanan berupa deposito berjangka, tabungan dan bentuk lainnya, menyalurkan dana kepada masyarakat dalam bentuk kredit.

\section{Pengertian Laporan Keuangan}

Laporan keuangan menurut (Saraswati, 2012) adalah hasil akhir dari proses akuntansi, sebagai hasil akhir dari proses akuntansi, laporan keuangan harus mampu menyajikan informasi yang berguna untuk mengembalikan keputusan oleh berbagai pihak.

Analisis Laporan keuangan Bank Perkreditan Rakyat bertujuan untuk menyediakana informasi yang menyangkut posisi keuangan, kinerja serta perubahan posisi keuangan. 


\section{a. Neraca}

Merupakan laporan keuangan utama yang diterbitkan di akhir periode akuntansi yaitu per tanggal 31 Desember.Didalamnya terdiri atas dua sisi yaitu aktiva (harta) disebelah kiridan passiva (hutang) ditambah modal disebelah kanan.

b. Laporan Laba Rugi

Merupakan laporan yang berisi beban dan penghasilan pada suatu periode akuntansi BPR.Dimana beban terdiri dari beban operasional, nonoperasional dan beban pajak penghasilan. Sedangkan penghasilan didapat dari pendapatan operasional dan non operasional.

c. Laporan perubahan ekuitas

Merupakan laporan yang menunjukkan perubahan dari ekuitas BPR yang digambarkan melalui peningkatan dan penurunan aset dan kekayaan BPR selama periode yang dilaporkan.

\section{Pengertian Tingkat Kesehatan Bank}

Tingkat kesehatan bank yaitu penilaian hasil dari kondisi Bank yang dilakukan terhadap resiko dan kinerja bank, dengan kata lain tingkat kesehatan bank yaitu cerminansebuah bank dalam menjalankan fungsinya dengan baik. Dengan kata laintingkat kesehatan bank merupakan hasil penelitian kualitatif atas berbagai aspek yang berpengaruh terhadap kondisi atau kinerja suatu bank melalui penilaian faktor permodalan, kualitas asset, manajemen, rentabilitas, likuiditas. (Taswan, 2006) Kesehatan Bank yaitu sebagai kemampuan suatu bank dalam melaksanakan kegiatan operasionalnya dengan normal.

a. Tata cara Penilaian Tingkat Kesehatan Bank BPR

Sesuai dengan SK Direksi BI No.30/12/Dir pasal 2 tentang tata cara penilaian tingkat kesehatan bank Bank Perkreditan Rakyat terdiri atas:

1) Tingkat kesehatan bank pada dasarnya dinilai dengan pendekatan kualitatif atas berbagai aspek yang berpengaruh terhadap kondisi dan perkembangan suatu bank.

2) Pendekatan kualitatif sebagaimana dimaksud dalam ayat (1) dilakukan dengan penilaian terhadap faktor-faktor permodalan, kualitas aktiva produktif, manajemen, rentabilitas, dan likuiditas.

Sesuai dengan SK Direksi BI No. 30/12/KEP/DIR tanggal 30 april 1997 tersebut juga ditetapkan bobot masing-masing untuk faktor CAMEL sebagai berikut: 
Tabel 2

Faktor Penilaian dan Bobotnya Dalam Penilaian Kesehatan Bank

\begin{tabular}{|c|l|l|c|}
\hline No & $\begin{array}{c}\text { Faktor yang } \\
\text { dinilai }\end{array}$ & \multicolumn{1}{|c|}{ Komponen } & Bobot \\
\hline 1 & Pemodalan & $\begin{array}{l}\text { Rasio modal terhadap aktiva } \\
\text { tertimbang menurut resiko (ATMR) }\end{array}$ & $30 \%$ \\
\hline 2 & $\begin{array}{l}\text { Kualitas aktiva } \\
\text { produktif }\end{array}$ & $\begin{array}{l}\text { a. Rasio aktiva produktif yang } \\
\text { diklasifikasikan terhadap aktiva } \\
\text { produktif } \\
\text { Rasio penyisihan aktiva produktif } \\
\text { yang dibentuk terhadap } \\
\text { penyisihan penghapusan aktiva } \\
\text { produktif yang dibentuk }\end{array}$ & $5 \%$ \\
\hline 3 & Manajemen & $\begin{array}{l}\text { a. Manajemen Resiko } \\
\text { b. Manajemen Umum }\end{array}$ & $10 \%$ \\
\hline 4 & Rentabilitas & $\begin{array}{l}\text { a. Rasio terhadap rata-rata volume } \\
\text { usaha } \\
\text { b. Rasio biaya operasional terhadap } \\
\text { pendapatan operasional }\end{array}$ & $5 \%$ \\
\hline 5 & Likuiditas & $\begin{array}{l}\text { a. Rasio alat likuid terhadap hutang } \\
\text { lancer dana yang diterima } \\
\text { b. Rasio kredit terhadap dana yang } \\
\text { diterima }\end{array}$ & $5 \%$ \\
\hline
\end{tabular}

Sumber: tata cara penilaian tingkat kesehatan BPR bank indonesia booklet SK direksi No.30/12/KEP/DIR tgl 30 April 1997

Tabel 3

Predikat Penilaian Kesehatan Bank

\begin{tabular}{cc}
\hline Nilai Kredit & Predikat \\
\hline $81-100$ & Sehat \\
$66-<81$ & Cukup sehat \\
$51-<66$ & Kurang sehat \\
$0-<51$ & Tidak sehat \\
\hline
\end{tabular}

Sumber: Booklet SK Direksi Bank Indonesia Nomor 30/12/KEP/DIR tanggal 30 April 1997 Tentang Tata Cara Penilaian Tingkat Kesehatan Bank Perkreditan Rakyat.

Unsur Penilaian Tingkat Kesehatan Bank dalam analisis CAMEL:

1. Permodalan (Capital)

Modal yaitu sumber pihak pertama dimana sejumlah dana yang diinvestasikan oleh pemilik untuk pendirian suatu bank. (Taswan, 2006) Modal yaitu dana yang diinvestasikan oleh pemilik dalam rangka pendirian 
badan usaha yang dimaksudkan untuk membiayai kegiatan usaha bank di samping untuk memenuhi regulasi yang ditetapkan oleh otoritas moneter.

Menurut Bank Indonesia standar yang diterapkan tentang kewajiban penyediaan modal minimum atau Capital Adequacy Ratio(CAR) sebesar 8\%. Capital Adequacy Ratio (CAR) dihitung untuk mengukur seberapa kuat permodalan bank menutupi resiko yang ada pada bank. Rasio ini digunakan untuk menilaian keamanan dan kesehatan bank dari sisi modal pemiliknya.

Semakin tinggi resiko Capital Adequacy Ratio (CAR), maka semakin baik kinerja Bank tersebut. Tinggi rendahnya Capital Adequacy Ratio (CAR) suatu bank akan dipengaruh oleh 2 faktor yaitu besarnya modal yang dimiliki bank dan jumlah Aktiva Tertimbang Menurut Resiko (ATMR) yang dikelola oleh bank tersebut. ATMR merupakan penjumlahan pos-pos aktiva setelah masing-masing pos dikalikan dengan bobotnya.

$$
C A R=\frac{\text { Modal }}{A T M R}=8 \%
$$

Modal $=$ Modal Inti + Modal Pelengkap

Penilaian permodalan berdasarkan nilai kredit faktor:

1) Bobot faktor penilaian $30 \%$

2) Rasio $8 \%$ mendapatkan nilai kredit 81 , dan untuk setiap kenaikan $0,1 \%$ dimulai dari $8 \%$ nilai kredit ditambah 1 hingga maksimal 100 sehingga nilai kredit dapat dirumuskan sebagai berikut:

3) Rasio kurang dari $8 \%$ mendapat nilai kredit 65 dan untuk setiap penurunan $0,1 \%$ dimulai dari 79 nilai kredit dikurangi 1 hingga minimum 0 sehingga kreditnya dirumuskan sebagai berikut:

$$
\text { Nilai Kredit }=\frac{\text { Rasio }}{0,1 \%}-1
$$

a. Kualitas Aktiva Produktif (Asset Quality)

KualitasAktivaProduktifmerupakanrasioantaraaktiva produktif yangdiklasifikasikan (APYD)terhadap totalaktiva produktif.APYD merupakan aktivaproduktif baikyangsudahmaupunyang mengandung potensi tidak memberikan penghasilan atau menimbulkan kerugian, sedangkan Total Aktiva Produktif merupakan total dari penanaman dana Bank dalam bentuk kredit, suratberharga, penyertaandan penanaman lainnya yang dimaksudkan untuk memperoleh penghasilan.Sehingga semakin kecil KAP menunjukkan semakin efektif kinerja Bank untuk menekan APYD serta memperbesar total aktiva produktif yang akan memperbesar pendapatan, sehingga laba yang dihasilkan semakin bertambah(Syahyunan, 2002)

Penilaian didasarkan kepada kualitas aktiva yang dimiliki bank. Rasio yang diukur ada 2 macam yaitu: 
1) Rasio Aktiva Produktif Yang Diklasifikasikan terhadap Aktiva Produktif (rasio APYD terhadap AP), APYD yaitu penjumlahan aktiva produktif seperti non lancar sesudah dikalikan bobot. Untuk mengukur tingkat kemungkinan diterimanya kembali dana yang ditanamkan. Semakin kecil rasio KAP, jadi semakin besar tingkat kemungkinan diterimanya kembali dana yang ditanamkan.

2) Rasio Penyisihan Penghapusan Aktiva Produktif Terhadap Penyisihan Penghapusan Aktiva Produktif Yang Wajib Dibentuk (rasio PPAP terhadap PPAPWD) yaitu untuk menunjukkan kemampuan bank dalam menjaga kolektabilitas atau pinjaman yang disalurkan semakin baik.

Dengan Formula:

$$
K A P=\frac{\text { Kredit Yang Diberikan }}{\text { Total Aktiva }} \times 100 \%
$$

Kriteria Penilaian Kualitas Aktiva Produktif ( KAP )

a) Sehat : $<10,36 \%$

b) Cukup Sehat : $10,36 \%-12,60$

c) Kurang Sehat : $12,61 \%-14,85 \%$

d) Tidak Sehat : $14,86 \%$ ke atas

Penilaian berdasarkan nilai kredit faktor :

1. Bobot faktor penilaian $25 \%$

2. Rasio $22,5 \%$ atau lebih dinilai 0

3. Setiap penurunan $0,15 \%$ dimulai dari $22,5 \%$ nilai kredit ditambah 1 hingga maksimum 100 sehingga nilai kreditnya dapat dirumuskan sebagai berikut:

$$
\begin{gathered}
\text { Nilai Kredit }=\frac{22,5 \%-A n g k a \text { Rasio }}{0,15 \%}= \\
\text { Rasio PPAP }=\frac{P P A P}{P P A P W D} \times 100 \%
\end{gathered}
$$

Penggolongan dari rasio :

a) Sehat : $81 \%$ ke atas

b) Cukup Sehat : $66 \%-80,99 \%$

c) Kurang Sehat : $51 \%-65,99 \%$

Penilaian berdasarkan nilai kredit faktor :

1. Bobot faktor penilaian $5 \%$

2. Rasio $0 \%$ dinilai 0

3. Untuk setiap kenaikan $1 \%$ dimulai dari $0 \%$ nilai kredit ditambah 1 sampai maksimum 100, sehingga nilai kreditnya dapat dirumuskan sebagai berikut :

$$
\text { Nilai Kredit }=\frac{\text { Angka Rasio }}{1 \%}
$$


b. Manajemen (management)

Menurut (J Weston Frend, 2018) Manajemen keuangan adalah memaksimumkan nilainya dan menaikan kesejahteraan pemilik, yang konsekuennya adalah pengguna sumber daya secara efisien.

c. Rentabilitas (Earning)

Menurut (Muljono,1995) Rasiorentabilitas suatu perusahaan menunjukkan perbandingan antara laba yang diperoleh perusahaan dengan aktiva atau modal yang diperlukan untuk menghasilkan laba.

Penilaian rentabilitas diukur dengan 2 macam kategori yaitu :

1) Rasio laba terhadap total asset (Return on Asset - ROA)

Menurut (Dietrich al et, 2001)Return on Assets(ROA) adalah menunjukkan kemampuan modal yang diinvestasikan dalam total aktiva untuk menghasilkan laba perusahaan. Semakin tinggi Return on Assets(ROA) maka kemungkinan pembagian dividen jugasemakin banyak.

Dengan Formula :

$$
R O A=\frac{\text { Laba Sebelum Pajak }}{\text { Total Aktiva }} \times 100 \%
$$

Penggolongan penilaian diatas adalah :

a) Sehat : 1,22 ke atas

b) Cukup Sehat : 0,99\% - 1,21\%

c) Kurang Sehat : 0,77\% - 0,98\%

d) Tidak Sehat : Kurang dari 0,76\%

Penilaian berdasarkan nilai kredit faktor :

1. Bobot faktor penilaian $5 \%$

2. Rasio $0 \%$ dinilai 0

3. Untuk setiap kenaikan $0,05 \%$ dimulai dari $0 \%$ nilai kredit ditambah 1 sampai maksimum 100, sehingga nilai kreditnya dapat dirumuskan sebagai berikut :

$$
\text { Nilai Kredit }=\frac{\text { Angka Rasio }}{0,015 \%}+1
$$

2) Rasio beban operasional terhadap pendapatan operasional (BOPO)

Menurut (Dietrich al et, 2001)Rasio BOPO digunakanuntuk mengukurefisiensioperasional bank, denganmembandingkan biaya operasional terhadap pendapatanoperasional.Semakin kecil rasio BOPO, maka semakin efesien suatu bank dalam melakukan kegiatan operasionalnya, karena biaya yang dikeluarkan lebih kecil dibandingkan pendapatan yang diterima.

Dengan Formula :

$$
\text { BOPO }=\frac{\text { Beban Operasional }}{\text { Pendapatan Operasional }} \times 100 \%
$$

Penggolangan penilaian di atas : 
a) Sehat : Kurang dari $93,52 \%$

b) Cukup Sehat : 93,53\% - 94,72\%

c) Kurang Sehat : 94,73\% - 95,92\%

d) Tidak Sehat : 95,93\% ke atas

Cara penilaian berdasarkan nilai kredit faktor :

1. Bobot faktor penilaian $5 \%$

2. Rasio $100 \%$ atau lebih dinilai 0

3. Untuk setiap penurunan $0,08 \%$ dimulai dari $100 \%$ nilai kredit ditambah 1 sampai maksimum 100, sehingga nilai kreditnya dapat dirumuskan sebagai berikut :

d. Likuiditas (Liquidity)

$$
\text { Nilai Kredit }=\frac{100 \%-\text { Angka Rasio }}{0,08 \%}
$$

Menurut (Muljono,1995) Likuiditas pada umumnya didefinisikan sebagai kepemilikan sumber dana yang memadai untuk seluruh kebutuhan dan kewajiban yang akan jatuh tempo.

Penilaian dalam unsur ini yaitu didasarkan pada dua rasio yaitu:

1) Cash Ratio (CR)

Menurut (Brigham,2001)Cash Ratioadalah salah satu ukuran dari rasio likuiditas (Liquidity Ratio) yang merupakan kemampuan perusahaan memenuhi kewajiban jangka pendeknya (c melalui sejumlah kas yang dimiliki perusahaan. Semakin tinggi Cash Ratiomenunjukan kemampuan kas perusahaan untuk memenuhi kewajiban jangka pendeknya.

Dengan Formula :

$$
\text { Cash Ratio }(C R)=\frac{\text { Aktiva Lancar }}{\text { Hutang Lancar }} \times 100 \%
$$

Penggolongan penilaian di atas :

a) Sehat : 4,05\% ke atas

b) Cukup Sehat : 3,30\% - 4,04\%

c) Kurang Sehat : 2,55\%-3,29\%

d) Tidak Sehat : Kurang dari 2,54\%

Cara penilaian berdasarkan nilai kredit faktor :

1. Bobot faktor penilaian $5 \%$

2. Rasio $0 \%$ dinilai 0

3. Untuk setiap penurunan $0,05 \%$ dinilai kredit ditambah 1 sampai maksimum 100, sehingga nilai kreditnya dapat dirumuskan sebagai berikut:

$$
\text { Nilaikredit }=\frac{\text { Rasio }}{0,05 \%}+1
$$




\section{2) Loan to deposit ratio (LDR)}

Menurut (afriyeni afriyeni, 2018)Loan to Deposit Ratio (LDR) adalah jenis rasio yang digunakan untuk mengukur sejauh mana kemampuan bank dalam memenuhi kewajiban yang bersifat jangka pendek (likuiditas) dengan cara membagi total jumlah kredit terhadap total Dana Pihak Ketiga atau DPK.

Dengan Formal :

Penggolongan penilaian diatas:

a) Sehat : Kurang Dari $94,75 \%$

b) Cukup Sehat : $98,5 \%-95 \%$

c) Kurang Sehat : $102,25 \%-98,75 \%$

d) Tidak Sehat :Lebih Dari 102,5\%

Penilaian berdasarkan nilai kredit faktor :

1. Bobot faktor penilaian $5 \%$

2. Rasio $0 \%$ dinilai 0

3. Untuk setiap penurunan $0,05 \%$ nilai kredit ditambah 1 sampai maksimum100, sehingga nilai kreditnya dapat dirumuskan sebagai berikut :

$$
\text { Nilai Kredit }=\frac{115 \%-\text { Angka Rasio }}{1 \%}+4
$$

\section{METODE PENELITIAN}

Dalam pengumpulan data dan bahan untuk melakukan penelitian ini, penulis menggunakan metode dengan dua cara sebagai berikut :

1. Metode Pengumpulan Data

a. Studi Lapangan (field research)

Peninjauan langsung ke objek penelitian dipilih untuk meneliti hasil data primer.Penelitian langsung ke lapangan ini akan membantu penulis untuk melengkapi data yang diperlukan.Adapun cara riset lapangan ini adalah dengan mewawancarai pihak-pihak yang berkepentingan dalam hal ini adalah perusahaan atau instansi yang terkait.

b. Studi Kepustakaan (Library research)

Penelitian ini dilakukan dengan cara mempelajari buku-buku, makalahmakalah,artikel-artikel, bacaan laporan-laporan dan publikasi yang berhubungan dengan objek penelitian.

2. Metode Analisis Data

Dalam menganalisis data, penulis menggunakan analisis data kualitatif dan kuantitatif. Dimana metode kualitatif menggambarkan, memahami dan menjelaskan data yang diteliti selama penelitian berlangsung, sedangkan kuantitatif. 


\section{HASIL DAN PEMBAHASAN}

1. Permodalan (capital)

Menurut (Taswan, 2006) Modal yaitu dana yang diinvestasikan oleh pemilik dalam rangka pendirian badan usaha yang dimaksudkan untuk membiayai kegiatan usaha bank di samping untuk memenuhi regulasi yang ditetapkan oleh otoritas moneter.

Penilaian terhadap permodalan PT. BPR Ganto Nagari 1954 Lubuk Alung menggunakan rasio CAR yang merupakan perbandingan antara modal dengan aktiva tertimbang menurut resiko. Dapat diketahui pada tabel dibawah ini :

Tabel 4

Capital Adequacy Ratio (CAR) PT. BPR Ganto Nagari 1954 Lubuk Alung Tahun 2016 - 2017

\begin{tabular}{ccccc}
\hline \multirow{2}{*}{ Keterangan } & \multicolumn{4}{c}{ Tahun } \\
\cline { 2 - 5 } & \multicolumn{3}{c}{$\mathbf{2 0 1 6}$} & \multicolumn{2}{c}{$\mathbf{2 0 1 7}$} \\
\cline { 2 - 5 } & Jumlah & Peningkatan & Jumlah (Rp) & Peningkatan \\
& $(\mathrm{Rp})$ & $(\%)$ & $(\%)$ \\
a. Jumlah modal & 2.721 .650 & - & 2.981 .570 & $9,55 \%$ \\
b. Jumlah ATMR & 22.531 .933 & - & 24.710 .701 & $9,67 \%$ \\
\cline { 2 - 5 } CAR = a/bx 100\% & \multicolumn{2}{c}{$\mathbf{1 2 , 0 8 \%}$} & $\mathbf{1 2 , 0 7 \%}$ \\
\hline
\end{tabular}

Sumber Data : PT. Bank Perkredian Rakya Ganto Nagari 1954 Lubuk Alung

Perhitungan nilai kredit $(\mathrm{NK})$ rasio $\mathrm{CAR}$

Nilai Kredit (NK) $2016=\frac{12,08 \%}{0,1 \%}+1=121,8$

$$
\text { Nilai Kredit }(\mathrm{NK})=\frac{\text { Rasio }}{0,1 \%}+1
$$

$$
\text { Nilai Kredit (NK) } 2017=\frac{12,07 \%}{0,1 \%}+1=121,7
$$

Dari tabel 4 diatas dapat dilihat bahwa resiko kecukupan modal (CAR) mengalami penurunan pada tahun 2016 sebesar 0,1\% dikarenakan terjadinya penurunan modal sebesar 9,55\% kecil dari pada peningkatan ATMR 9,67\%. Sedangkan untuk tahun 2016-2017 lebih besar dari 8\% berarti dikatakan SEHAT dalam menyediakan pemodalannya untuk menghadapi resiko-resiko yang mungkin timbul.

2. Analisis Terhadap Faktor Kualitas Aktiva Produktif (Assets Quality)

Penilaian KAP yang dimiliki dapat diukur dengan 2 cara yaitu :

a. Rasio KAP (Rasio Aktiva Produktif Yang Diklasifikasikan /APYD terhadap Aktiva Produktif) .APYD menggambarkan Aktiva Produktif yang kurang lancar, diragukan, atau macet. Semakin besar APYD tersebut maka semakin besar kondisi Aktiva Produktif yang potensial untuk tidak dapat ditagih atau macet.

b. 
Tabel 5

Laporan Kolektibilitas Aktiva Produktif PT. BPR Ganto Nagari 1954 Lubuk Alung Tahun 2016 (Rp.000)

\begin{tabular}{lrrr}
\hline \multicolumn{1}{c}{ Komponen } & Nominal & \multicolumn{1}{c}{$\begin{array}{c}\text { Bobot } \\
(\%)\end{array}$} & \multicolumn{1}{c}{$\begin{array}{c}\text { Aktiva Yang } \\
\text { Diklasifikasikan }\end{array}$} \\
\hline A. Aktiva Produktif yang & & & \\
$\quad$ diklasifikasikan (APYD) & & 0 & 0 \\
. Lancar & 7.011 .327 & $50 \%$ & 327.005 \\
. Kurang Lancar & 654.011 & $75 \%$ & 156.759 \\
. Diragukan & 209.012 & $100 \%$ & 1.620 .690 \\
. Macet & 1.620 .690 & & $\mathbf{2 . 1 0 4 . 4 5 4}$ \\
Jumlah APYD & & & \\
\hline
\end{tabular}

B. Aktiva Produktif

. Kredit yang Diberikan

12.555 .411

. Penempatan pada Bank

7.011.327

Lain

Jumlah Aktiva Produktif

19.566.738

Sumber : PT. Bank Perkreditan Rakyat Ganto Nagari 1954 Lubuk Alung

Tabel 6

Laporan Kolektibilitas Aktiva Produktif PT. BPR Ganto Nagari 1954

Lubuk Alung Tahun 2017 (Rp.000 )

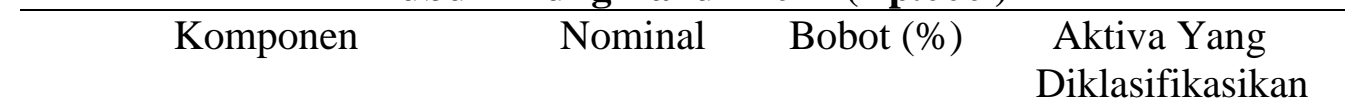

A. Aktiva Produktif yang diklasifikasikan

$\begin{array}{lrrr}\text { (APYD) } & 8.833 .553 & 0 & 0 \\ \text {. Lancar } & 396.347 & 50 \% & 198.173 \\ \text {. Kurang Lancar } & 265.950 & 75 \% & 199.462 \\ \text {. Diragukan } & 1.519 .855 & 100 \% & 1.519 .855 \\ \text {. Macet } & & & \mathbf{1 . 9 1 7 . 4 9 0} \\ \text { Jumlah APYD } & & & \end{array}$

B. Aktiva Produktif

. Kredit yang Diberikan

12.555 .411

. Penempatan pada

7.011 .327

Bank Lain

Jumlah Aktiva Produktif

1.917.490

Sumber : PT. Bank Perkreditan RakyatGanto Nagari 1954 Lubuk Alung

Perhitungan Rasio KAP PT.Bank Perkreditan RakyatGanto Nagari 1954

Lubuk Alung adalah sebagai berikut :

Perhitungan nilai kredit (NK) Rasio KAP : 


$$
\begin{aligned}
& \text { KAP }=\frac{\text { Jumlah Aktiva Produktif yang Diklasifikasikan }}{\text { Jumlah Aktiva Produktif }} \times 100 \% \\
& \text { KAP } 2016=\frac{2.104 .454}{19.566 .738} \times 100 \%=0,10 \% \\
& \text { KAP } 2017=\frac{1.917 .490}{20.874 .668} \times 100 \%=0,91 \% \\
& \text { Perhitungan nilai kredit (NK) Rasio KAP : } \\
& \qquad \text { NK } 2016=\frac{22,5 \%-0,10 \%}{0,15 \%}=149 \text { (maksimum 100) } \\
& \qquad \text { NK } 2017=\frac{22,5 \%-0,91 \%}{0,15 \%}=148 \text { (maksimum 100) }
\end{aligned}
$$

PT. BPR Ganto Nagari 1954 Lubuk Alung selama periode 2016-2017 dapat menjaga rasio KAP dibawah 10,35\% dapat dikatakan sehat.

c. Rasio PPAP (Rasio Penyisihan Penghapusan Aktiva Produktif terhadap Penyisihan Penghapusan Aktiva Produktif yang Wajib Dibentuk/PPAPYD).

PPAPYD yaitu dibentuk untuk menutup resiko kemungkinan kerugian. Semakin besar PPAP ini dicadangkan dari modal.Hasil perhitungan rasio PPAP pada PT. BPR Ganto Nagari 1954 Lubuk Alung tahun 2016-2017.

\section{Tabel 7}

Laporan Kolektibilitas Aktiva Produktif PT. BPR Ganto Nagari 1954 Lubuk Alung Tahun 2016 (Rp.000)

\begin{tabular}{lrrr}
\hline Komponen & Nominal & \multicolumn{1}{c}{$\begin{array}{c}\text { Bobot } \\
(\%)\end{array}$} & \multicolumn{1}{c}{$\begin{array}{c}\text { Aktiva Yang } \\
\text { Diklasifikasikan }\end{array}$} \\
\hline PPAP & & & $\mathbf{7 7 5 . 6 1 2}$ \\
PPAPWD & & & \\
. Lancar & 7.011 .327 & $0,5 \%$ & 35.056 .635 \\
. Kurang Lancar & 654.011 & $10 \%$ & 654.011 \\
. Diragukan & 209.012 & $50 \%$ & 104.506 \\
. Macet & 1.620 .690 & $100 \%$ & 1.620 .690 \\
Jumlah APYD & & & $\mathbf{3 7 . 4 3 5 . 8 4 2}$ \\
\hline
\end{tabular}

Sumsber Data : PT. Bank Perkreditan RakyatGanto Nagari 1954 Lubuk Alung 
Tabel 8

Laporan Kolektibilitas Aktiva Produktif PT. BPR Ganto Nagari 1954 Lubuk Alung Tahun 2017 (Rp.000)

\begin{tabular}{lrrr}
\hline Komponen & Nominal & \multicolumn{1}{c}{$\begin{array}{c}\text { Bobot } \\
(\%)\end{array}$} & \multicolumn{2}{c}{$\begin{array}{c}\text { Aktiva Yang } \\
\text { Diklasifikasikan }\end{array}$} \\
\hline PPAP & & & $\mathbf{6 . 4 7 8 . 6 6 4}$ \\
PPAPWD & & & \\
. Lancar & 8.833 .553 & $0,5 \%$ & 44.167 .765 \\
. Kurang Lancar & 396.347 & $10 \%$ & 396.347 \\
. Diragukan & 265.950 & $50 \%$ & 132.975 \\
. Macet & 1.519 .855 & $100 \%$ & 1.519 .855 \\
Jumlah APYD & & & $\mathbf{4 6 . 2 1 6 . 9 4 2}$ \\
\hline
\end{tabular}

Sumber Data : PT.Bank Perkreditan RakyatGanto Nagari 1954 Lubuk Alung Perhitungan Rasio PPAP :

Rasio PPAP $=\frac{\text { PPAP }}{\text { PPAPWD }} \times 100$

Rasio PPAP $2016=\frac{775.612}{37.435 .842} \times 100 \%=2,0 \%$

Rasio PPAP $2017=\frac{6.478 .664}{46.216 .942} \times 100 \%=1,4 \%$

Perhitungan nilai kredit (NK) PPAP :

Nilai Kredit (NK) $2016=\frac{2,0 \%}{1 \%}=2$

Nilai Kredit (NK) $2017=\frac{1,4 \%}{1 \%}=1,4$

PT. BPR Ganto Nagari 1954 Lubuk Alung selama periode 2016-2017 tidak dapa menjaga rasio PPAP sebesar $81 \%$ dapat dikatakan sehat.

3. Rentabilitas (Earning)

Perhitungan rentabilitas dengan menggunakan dua rasio yaitu Return on Asset (ROA) merupakan perbandingan laba sebelum pajak dengan rata-rata total aktiva, dan Rasio Biaya Operasional terhadap Pendapatan Operasional (BOPO) merupakan perbandingan pendapatan operasional.Serta dapat dilihat dari tabel di bawah ini. 
Tabel 9

Perhitungan Faktor Rentabilitas PT. BPR Ganto Nagari 1954 Lubuk Alung Tahun 2016-2117 (Rp.000)

\begin{tabular}{llrr}
\hline No & \multicolumn{1}{c}{ Komponen } & \multicolumn{2}{c}{ Tahun } \\
\cline { 3 - 4 } & & $\mathbf{2 0 1 6}$ & $\mathbf{2 0 1 7}$ \\
& & 582.570 & 580.722 \\
1 & Laba Sebelum Pajak & 27.664 .542 & 31.384 .033 \\
2 & Total Aktiva & 3.952 .708 & 4.325 .671 \\
3 & Beban Operasional & 4.554 .592 & 4.926 .493 \\
\hline
\end{tabular}

SumberData : $\quad$ PT. Bank Perkreditan RakyatGanto Nagari 1954 Lubuk Alung 1. Perhitungan Rasio ROA

$$
\begin{aligned}
& \text { ROA }=\frac{\text { Laba Sebelum Pajak }}{\text { Total Aktiva }} \times 100 \% \\
& \text { ROA } 2016=\frac{582.570}{27.664 .542} \times 100 \%=2,1 \% \\
& \text { ROA } 2017=\frac{580.722}{31.384 .033} \times 100 \%=1,8 \%
\end{aligned}
$$

Perhitungan Nilai Kredit (NK) ROA :

$$
\begin{aligned}
N K 2016= & \frac{2,1 \%}{0,015 \%}=140(\text { maksimum } 100) \\
& N K 2017=\frac{1,8 \%}{0,015 \%}=120(\text { maksimum } 100)
\end{aligned}
$$

Berdasarkan hasil perhitungan diatas, PT BPR ganto Nagari 1954 Lubuk Alung dapat menjaga ROA tetap berada $1,215 \%$ dapat dikatakan sehat.

Perhitungan Rasio BOPO

$$
\begin{aligned}
& \text { BOPO }=\frac{\text { Beban Operasional }}{\text { Pendapatan Operasional }} \times 100 \% \\
& \text { BOPO } 2016=\frac{3.952 .708}{4.554 .592} \times 100 \%=86 \% \\
& \text { BOPO } 2017=\frac{4.325 .671}{4.926 .493} \times 100 \%=87 \% \\
& \text { Perhitungan Nilai Kredit (NK) BOPO : } \\
& \text { NK } 2016=\frac{100 \%-86 \%}{0,08 \%}=175(\text { maksimum } 100) \\
& \text { NK } 2017=\frac{100 \%-87 \%}{0,08 \%}=162(\text { maksimum } 100)
\end{aligned}
$$

BOPO PT. BPR Ganto Nagari 1954 pada tahun 2016 86\% dan ditahun 2017 87\% maka dapat dikatakan sehat.

4. Likuiditas (Liquidity) 
Likuiditas yaitu kemampuan untuk membayar kewajiban financial jangka pendek tepat pada waktunya yang ditunjukkan oleh besar kecilnya aktiva lancar.Penilaian likuiditas dimaksudkan untuk mengevaluasi kemampuan bank memelihara tingkat likuiditas yang memadai dan kecukupan manajemen resiko likuiditas.Penilaian dalam unsur ini yaitu didasarkan pada dua rasio yaitu.

\section{Tabel 10}

Perhitungan Faktor Likuiditas PT. BPR Ganto Nagari 1954 Lubuk Alung Tahun 2016-2017 (Rp.000)

\begin{tabular}{|c|c|c|c|}
\hline \multirow[t]{2}{*}{ No } & \multirow[t]{2}{*}{ Komponen } & \multicolumn{2}{|c|}{ Tahun } \\
\hline & & 2016 & 2017 \\
\hline 1. & $\begin{array}{l}\text { Cash Ratio } \\
\text { a. Aktiva Lancar } \\
\text { - Kas } \\
\text { - Antar Bank Aktiva } \\
\text { Jumlah } \\
\text { b. Hutang Lancar } \\
\text { - Kewajiban Segera } \\
\text { - Tabungan } \\
\text { - Deposito } \\
\text { Jumlah }\end{array}$ & $\begin{array}{r}175.423 \\
1.024 .980 \\
\mathbf{1 . 2 0 0 . 4 0 3} \\
79.931 \\
12.110 .582 \\
10.439 .000 \\
\mathbf{1 0 2 . 4 8 0 . 5 8 2}\end{array}$ & $\begin{array}{r}277.361 \\
972.730 \\
\mathbf{1 . 2 5 0 . 0 9 1} \\
87.229 \\
13.324 .045 \\
12.336 .300 \\
\mathbf{1 1 2 . 8 8 9 . 3 4 5}\end{array}$ \\
\hline 2. & $\begin{array}{l}\text { Loan to Deposit Ratio } \\
\text { a. Kredit yang diberikan } \\
\text { b. Dana Pihak ketiga dan Modal } \\
\text { - Tabungan } \\
\text { - Depositi } \\
\text { - Modal } \\
\text { Jumlah }\end{array}$ & $\begin{array}{r}\mathbf{2 0 . 0 1 1 . 5 7 6} \\
12.110 .582 \\
10.439 .000 \\
2.721 .650 \\
\mathbf{2 5 . 2 7 1 . 2 3 2}\end{array}$ & $\begin{array}{r}\mathbf{2 1 . 8 9 5 . 3 0 0} \\
13.324 .045 \\
12.336 .300 \\
2.981 .570 \\
\mathbf{2 8 . 6 4 1 . 9 1 5}\end{array}$ \\
\hline
\end{tabular}

Sumber Data : PT. Bank Perkreditan Rakyat Ganto Nagari 1954 ubuk Alung

1. Perhitungan Cash Ratio (CR) :

$\mathrm{CR}=\frac{\text { Aktiva Lancar }}{\text { Hutang Lancar }} \times 100 \%$

CR $2016=\frac{1.200 .403}{102.480 .582} \times 100 \%=11 \%$

CR $2017=\frac{1.250 .091}{112.889 .345} \times 100 \%=11 \%$

Perhitungan Nilai Kredit (NK)

$\mathrm{NK}=\frac{\text { Angka Rasio }}{0,05 \%} \times 1$

NK $2016=\frac{11 \%}{0,05 \%} \times 1=220$ 
NK $2017=\frac{11 \%}{0,05 \%} \times 1=220$

Cash Ratio PT. Bank Perkredian Rakya Ganto Nagari 1954 Lubuk Alung pada tahun 2016 sebesar 11\% dan pada tahun 2017 11\%. Dapat dikelompokan Sehat.

2. Perhitungan Loan to Deposit Ratio ( LDR )

$$
\begin{aligned}
& \mathrm{LDR}=\frac{\text { Kredit yang Diberikan }}{\text { Dana Pihak ketiga }+ \text { Modal }} \times 100 \% \\
& \text { LDR } 2016=\frac{20.011 .576}{25.271 .232} \times 100 \%=79 \% \\
& \text { LDR } 2017=\frac{21.895 .300}{28.641 .915} \times 100 \%=76 \%
\end{aligned}
$$

Perhitungan Nilai Kredit (NK) LDR

$\mathrm{NK}=\frac{115 \%-\text { Angka Rasio }}{1 \%} \times 4$

NK $2016=\frac{115 \%-79 \%}{1 \%} \times 4=144($ maksimum 100$)$

LDR $2017=\frac{115 \%-76 \%}{1 \%} \times 4=165($ maksimum 100$)$

Loan to Deposit Ratio (LDR) PT. Bank Perkreditan Rakyat Ganto Nagari 1954 Lubuk Alung pada tahun 2016 sebesar 79\% dan tahun 2017 sebesar $76 \%$ berdasarkan hasil perhitungan tersebut, PT.Bank Perkreditan Rakyat Ganto Nagari 1954 Lubuk Alung dapat menjaga Loan to Deposit Ratio (LDR) tetap berada dibawah 94,75\%. Maka berdasarkan hal tersebut bank dapat dikatakan sehat.

\section{SIMPULAN}

Berdasarkan hasil analisis pada bab sebelumnya bahwa penelitian yang berjudul "Analisis Tingkat Kesehatan Bank Pada PT. Bank Perkreditan Rakyat Ganto Nagari 1954 Lubuk Alung" dapat disimpulkan sebagai berikut:

a. Capital Adequacy Ratio (CAR) pada PT. BPR Ganto Nagari 1954 Lubuk Alung untuk periode 2016-2017 dalam kategori sehat. Rasio permodalan yang diperoleh PT. BPR Ganto Nagari 1954 Lubuk Alung selama tahun 2016-2017 adalah sebesar 12,08\% (2016), 12,07\% (2017). Rasio rata-rata selama 2 tahun adalah $1 \%$ artinya masih diatas ketentuan yang di tetapkan Bank Indonesia.

b. KAP yang dimiliki PT. BPR Ganto Nagari 1954 Lubuk Alung untuk periode 2016-2017 sebesar 0,10\% (2016), 0,91\% (2017). Rasio PPAP yang diperoleh PT. BPR Ganto Nagari 1954 Lubuk Alung adalah sebesar 2,0\% tahun (2016), 1,4\% tahun (2017) dinyatakan sehat. Dengan hasil 
analisa yang menunjukkan bahwa dalam kurun 2 tahun terakhir Aktiva Produktif yang termasuk dalam kategori kredit macet mengalami peningkatan.

c. Rentabilitas yang didasarkan pada Return On Asset (ROA) PT. BPR Ganto Nagari 1954 Lubuk Alung dikatakan sehat dengan rasio Return On Asset (ROA) Sedangkan untuk rasio BOPO dalam 2 periode tergolong sehat, karena telah memenuhi kriteria sebagai bank yang sehat dengan rasio kurang dari 93,52\%, dimana PT. BPR Ganto Nagari 1954 Lubuk Alung juga berhasil meningkatkan pendapatannya.

d. Likuiditas yang didasarkan pada Cash Ratio dalam 2 tahun terakhir tergolong sehat, hal ini ditunjukkan dengan rasio yang dihasilkan seimbang yaitu sebesar $11 \%$. Sedangkan untuk Loan to Deposit Ratio ( LDR) pada tahun 2016-2017 adalah sebesar 79\% (2016), 76\% (2017).

\section{UCAPAN TERIMA KASIH}

Penulis mengucapkan terima kasih kepada pihak-pihak yang telah membantu dan mendukung penulis dalam mengerjakan Tugas Akhir ini. Kepada PT. BPR Ganto Nagari 1954 Lubuk Alung dan pimpinan serta dosen pembimbing Akademi Keuangan dan Perbankan "Pembangunan" yang telah memberi dukungan penuh sehingga terlaksananya penelitian ini.

\section{DAFTAR PUSTAKA}

Afriyeni, A. (2017). Profitabilitas Bank Perkreditan Rakyat Di Kota Padang Di Tinjau Dari Rasio Likuiditas. Jurnal Benefita: Ekonomi Pembangunan Manajemen Bisnis Dan Akuntansi. Volume 2. No. 1. http://doi.org/10.22216/jbe.v2i1.2104

Afriyeni, A., Fernos, J. (2018). Analisis Faktor-Faktor Penentu Kinerja Profitabilitas Bank Perkreditan Rakyat (BPR) Konvensional Di Sumatera Barat. Jurnal Benefita: Ekonomi Pembangunan, Manajemen Bisnis Dan Akuntansi Volume 3. Nomor 3. Hal. 325-335. http://doi.org/10.22216/jbe.v3i3.3623

Afriyeni, A. (2019). Analisis Rasio Keuangan Pada PT. Pegadaian (Persero) Cabang Ulak Karang. https://doi.org/10.17605/OSF.IO/Z9PW8

Anggraeni, O. (2011). Penilaian Tingkat Kesehatan Bank Dengan Menggunakan Metode Camel Pada Pt. Bank Pembangunan Daerah Jawa Tengah 20062009. Jurnal Telaah \& Riset Akuntansi, 3(1), 1-40.

Arifin, I. Z., \& Marlius, D. (2017). Analisis Kinerja Keuangan PT. Pegadaian Cabang Ulak Karang. https://doi.org/10.31227/osf.io/n2peu 
Badria, M., \& Marlius, D. (2019). Analisis Rasio Likuiditas Pada PT. Bank Perkreditan Rakyat (BPR) Lengayang. https://doi.org/10.31219/osf.io/esvb7

Brigham. (2001). Analisis Pengaruh Cash Ratio , Return On Assets , Growth , Firm Size , Debt To Equity Ratio Terhadap Dividend Payout Ratio : ( Studi Pada Perusahaan Manufaktur Yang Terdaftar Di Bursa Efek Indonesia Tahun 2008-2011).

Budiasih, Y. (2012). Struktur Organisasi, Desain Kerja, Budaya Organisasi Dan Pengaruhnya Terhadap Produktivitas Karyawan Studi Kasus Pada Pt . Xx di Jakarta. Jurnal Liquidity, 1(2), 99-105.

Dietrich al et. (2001). Return On Assets Terhadap Dividend Payout Ratio, 1-6.

Fernos J. (2017). Analisis Rasio Profitabilitas Untuk Mengukur Kinerja Pt. Bank Pembangunan Daerah Sumatera Barat. Vol. 01, No. 02, Juli 2017, 1(2), 107118.

Fitri, H. Y., \& Marlius, D. (2019). Analisis Rasio Likuiditas Pada PT. Bank Perkreditan Rakyat (BPR) Nagari Kasang. https://doi.org/10.31219/osf.io/bcs73

Handayani, M., \& Marlius, D. (2017). Analisis Tingkat Kesehatan PT. BPR Batang Kapas. https://doi.org/10.31227/osf.io/bq48z

Bank Indonesia. 1998. UU No tahun 1998, Tentang Perubahan TerhadapNo. 7 Tahun 1992, jakarta.

J Weston Frend, T. (2018). Analisis Rasio Rentabilitas Untuk Menilai, 1(1), 124-141.

Muljono. (1995). Kecukupan Modal Perbankan Yang Terdaftar Di Bursa Efek Jakarta, 3, 1-11.

Mustika, S., \& Marlius, D. (2019). Analisa Tingkat Kesehatan Keuangan PT. Bank Perkreditan Rakyat (BPR) Batang Palangki. https://doi.org/10.31219/osf.io/wupyh

Putri, Y. A., \& Marlius, D. (2018). Analisis Tingkat Kesehatan Bank Pada PT. Bank Perkreditan Rakyat (BPR) Jorong Kampuang Tangah Pariaman Cabang Padang. https://doi.org/10.31227/osf.io/r98pv 
Rahmayeli, D. S., \& Marlius, D. (2017). Analisis Kinerja Keuangan Pada PT. Bank Perkreditan Rakyat (BPR) Batang Kapas Pesisir Selatan. https://doi.org/10.31227/osf.io/sz5db

Sari, Y. P., \& Marlius, D. (2019). Analisis Rasio Profitabilitas Pada PT. Bank Negara Indonesia Syariah. https://doi.org/10.31219/osf.io/94bwq

Simorangkir, O. . (2012). Hukum Perbankan. 12-pH-268.

Sukmadi. (2014). Pengertian Bank Perkreditan Rakyat. 1994, (90462201140), 1-21.

Syahyunan. (2002). Kata kunci: Car, Nim, Ldr, Npl, Bopo, Kap Dan Perubahan laba., 2(1), 14-25.

Taswan. (2006). Analisis Laporan Keuangan Untuk Menilai Tingkat Kesehatan Keuangan. 